\title{
Genetic Relationships Among Species of the Genus Bothrops Based on RAPD Markers
}

\author{
Felipe Grazziotin and Sergio Echeverrigaray* \\ Instituto de Biotecnologia and Museu de Ciências Biológicas; Universidade de Caxias do Sul; Rua Francisco \\ Getúlio Vargas, 1130; 95001-970; Caxias do Sul - RS - Brazil
}

\begin{abstract}
The genetic relationships among 11 species of Bothrops found in Brazil were determined using random amplified fragment (RAPD) information. A total of 239 amplified bands were scored using 20 aleatory primers. Most of the bands (88.7\%) were polymorphic. Phylogenetic analysis of the data determined three similarity groups within Bothrops: Group I- B. alternatus, B. neuwiedi, B. cotiara, and B. jararacusu; Group II- B. insularis, B. jararaca, and B. erythromelas; and Group III- B. moojeni, B. leucurus, and B. atrox. These groups coincided with those obtained by other methods, indicating that RAPD's could be a useful tool for the evaluation of genetic relationships at the interspecific level.
\end{abstract}

Key words: Bothrops, RAPD, molecular markers, genetic relationship

\section{INTRODUCTION}

The "lancehead snakes" of the genus Bothrops (family Viperidae) is divided into 31 species, of which 19 occur in the Brazilian territory (Campbell and Lamar, 1989). Lancehead snakes are most frequently responsible for cases of human envenomation (89.04\%) in Brazil (Ministério da Saúde, 1991; Cardoso, 1992) and other countries of Latin America (Campbell and Lamar, 1989). Morphology has been widely used to classify and infer relationships among Bothrops species (Amaral, 1921; Hoge and Romano-Hoge, 1978; 1979), and to differentiate Bothrops from other related genera (Schatti and Kramer, 1993). However, relationships among members of the genus Bothrops remain controversial and unclear. The recent inclusion of the analysis of hemipenis morphology, the electrophoretic patterns of plasma proteins, venom proteins, and isozymes (Pesantes,
1989; Werman, 1992), helped to solve several issues but a number of questions remain unanswered.

In the last few years, in spite of controversies, the use of molecular techniques has contributed to the resolution of many systematic and phylogenetic problems (Patterson et al., 1993; Moritz and Hillis, 1996). Several techniques such as restriction fragment length polymorphism (RFLP), DNADNA hybridization, randomly amplified polymorphic DNA (RAPD), arbitrary fragment length polymorphism (AFLP), and DNA sequencing, have been used with success to clarify relationships at different phylogenetic levels (Crawford, 1990; Weising et al., 1995; Hillis et al., 1996). The apparent advantage of the RAPD analysis over other techniques is that it requires no foreknowledge about any particular gene in a target taxon, and that it is random with respect to the genome covering all of it if using a large

\footnotetext{
${ }^{*}$ Author for correspondance
} 
number of primers. RAPD analysis has been used in molecular ecology studies to determine taxonomic identity, assess kinship relationships, and analyze mixed genome samples (Hadrys et al., 1992), and in systematic studies at intraspecific (Master, 1995; Echeverrigaray et al., 2001) and interspecific levels (Master, 1995; Ryabinina et al., 1997).

In spite of the utility of DNA approaches solving systematic problems, the application of these techniques to the genus Bothrops (sensus stricto) and its relatives is limited to a few reports. Salomão et al.(1997) used mitochondrial DNA sequence analysis (565 bp region of the cytochrome $b$ gene) to evaluate the phylogenetic relationships among several species of neotropical pitvipers. Their results confirmed the monophyly of the Bothrops atrox group, the rooting of Bothriopsis within the genus Bothrops, and the sister-species relationships between $B$. jararaca and $B$. insularis.

The present study aimed to use RAPD markers to confirm previous data and to provide additional clarification of the relationships among several Brazilian Bothrops.

\section{MATERIAL AND METHODS}

The specimens used in this study and their localities are shown in Table 1. Total DNA was extracted from shed skins by a modification of the method reported by Bricker et al.(1996). To confirm the quality of the DNA extracts obtained form the skins, additional blood samples of the same animal (representatives of B. jararaca, and
B. moojeni) were collected by the cardiac puncture method (Branch, 1973), and DNA extracted by a procedure adapted from Hillel et al.(1989).

The 20 aleatory primers of kit A (Operon DNA Technologies, Alameda, Calif.), were used in this study. The polymerase chain reaction protocol used was a variation of that reported by Williams et al.(1990).

Reactions were performed in a $25 \square 1$ volume containing $50 \mathrm{mM} \mathrm{KCl} ; 10 \mathrm{mM}$ Tris- $\mathrm{HCl}(\mathrm{pH} 8.3)$; $3 \mathrm{mM} \mathrm{MgCl} 2 ; 0.25 \%$ Triton-X-100; $1.25 \mathrm{mM}$ of each dATP, dCTP, dTTP and dGTP (Pharmacia LKB Biotechn., Inc., NJ); 30ng of single decamer primer; 60 to $80 \mathrm{ng}$ of genomic DNA; and 1.5 units of Taq DNA polymerase (Pharmacia LKB Biotechn., Inc., NJ). DNA amplification was performed using a thermal cycler (model PTC100, MJ Research, Watertown, Mass.). PCR was carried out using $94^{\circ} \mathrm{C}$ for $1 \mathrm{~min}$; then 45 cycles of $94^{\circ} \mathrm{C}(1 \mathrm{~min}), 35^{\circ} \mathrm{C}(1 \mathrm{~min})$ and $72^{\circ} \mathrm{C}(2 \mathrm{~min})$, and finally $72^{\circ}$ for $3 \mathrm{~min}$. A negative control including all components except genomic DNA was included in all amplifications.

Following amplification, the RAPD products $(20 \mu \mathrm{l})$ were loaded in $1.5 \%$ agarose gels in $1 \mathrm{x}$ TBE buffer and separated by electrophoresis $(90$ volts during 3 hours). After electophoresis the amplification products were stained with ethidium bromide and photographed under UV light. The sizes of amplification products were determined by comparison to Lambda DNA digested with EcoRI and HindIII restriction enzymes.

Table 1 - List of the specimens examined in this study and their localities.

\begin{tabular}{llc}
\hline \multicolumn{1}{c}{ Taxon } & \multicolumn{1}{c}{ Locality } & Sample size \\
\hline B. jararaca & Caxias do Sul, RS (I); Cazuza Ferreira, RS (II) & 2 \\
B. moojeni & Goiania, GO (I); Brasilia, DF (II) & 2 \\
B. jararacussu & Juquitiba, SP (I); Brusque, SC (II) & 2 \\
B. alternatus & Caxias do Sul, RS (I); Jaquirana, RS (II) & 2 \\
B. atrox & Manaus, AM (I); Santarem, PA (II) & 2 \\
B. cotiara & Chapeco, SC (I); Videira SC (I) & 2 \\
B. insularis & Ilha Queimada Grande, SP (I, II) & 2 \\
B. leucurus & Porto Seguro, BA (I, II) & 2 \\
B. erythromelas & Gloria, BA (I); Caetite, BA (II) & 2 \\
B. neuwiedi & Pelotas, RS (I); São Borja, RS (II); Aquidauana, MS & 3 \\
Crotalus durissus terrificus & (III) Cazuza Ferreira, RS & 1 \\
Lachesis muta muta & Manaus, AM & 1 \\
\hline
\end{tabular}



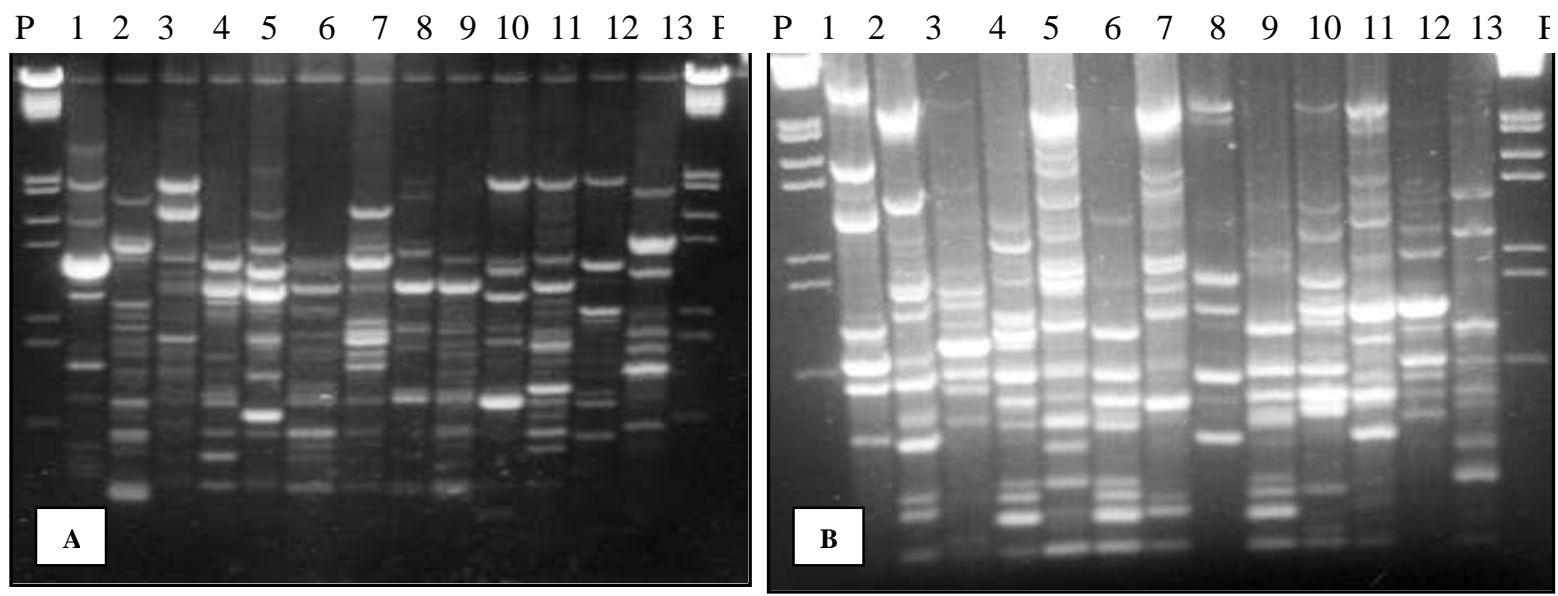

Figure 1 - RAPD products generated using (A) OPA-20 and (B) OPA-07. Each line represent a separate individual. Lines are: 1- B. alternatus; 2- B. neuwiedi; 3- B. cotiara; 4- B. moojeni; 5- B. jararacusu; 6- B. leucurus; 7- B. jararaca; 8- B. erythromelas; 9- B. atrox; 10- B. insularis I; 11 B. insularis II; 12- Lachesis muta; 13- Crotalus durissus terrificus; P- DNA size standard (Lambda EcoRI/HindIII).

Bands were scored as present (1) or absent (0). Only bands that were between 100 and 2500bp and that appeared consistently among three independent runs were rated. Bands that were not well defined were not included in the data set. Band-sharing analysis (Jaccard's coefficient) was conducted using NTSYS-pc (Rohlf, 1992). In order to assess the robustness of the phylogenetic hypotheses generated, we used three different algorithms: neighbor-joining, Fitch-Margoliash and polymorphism parsimony. The outgroups for tree rooting were Lacchesis muta and Crotalus durissus terrificus. Phylogenetic analysis was conducted using PHYLIP 3.5 (Felsenstein, 1993).

\section{RESULTS AND DISCUSSION}

Using the 20 aleatory decamer primers of kit A (Operon Techn.) to amplify genomic DNA from 21 individuals of 10 species of the genus Bothrops, and two representatives of the genera Lacchesis and Crotalus, a total of 239 bands were scored, ranging in size from 100 to $2500 \mathrm{bp}$. Between nine and 26 bands were scored for each primer. Of the total bands scored in this study, 212 or $88.7 \%$ showed variation.

An example of the patterns obtained by RAPD analysis of Bothrops species, and the representatives of Crotalus durissus and Lachesis muta, is shown in Figure 1. Combining the information supplied by several reactions, all the samples included in the study were differentiated.

Table 2 - Percentage of polymorphic bands within species, between groups, among Bothrops, and between two genera.

\begin{tabular}{lc}
\multicolumn{1}{c}{ Comparisons } & Polymorphism (\%) \\
\hline Within species of Bothrops & 28.5 \\
Within B. alternatus group & 60.52 \\
Within B. atrox group & 64.28 \\
Within B. jararaca group & 60.78 \\
B. alternatus vrs. B. atrox groups & 83.16 \\
B. alternatus vrs. B. jararaca groups & 82.96 \\
B. atrox vrs. B. jararaca groups & 83.42 \\
Among Bothrops & 90.0 \\
Bothrops vrs. Crotalus & 98.23 \\
\hline
\end{tabular}


As expected, the smallest differences occurred between two individual of the same species, nine polymorphic bands were detected between the two representatives of $B$. moojeni, and the highest differences, 95 bands, occurred between $B$. alternatus and $C$. durissus. The ability to differenciate all tested animals supports the idea that RAPD markers may be practically applied for the identification of individuals and populations of snakes, as has been proved for other taxa (Hadrys et al., 1992).

The evaluation of the mean number of polymorphic bands at the different phylogenetic levels (Table 2) showed that a well defined and relatively constant percentage was present at each level.

The cladograms obtained by the three algorithms used in this study are shown in Figure 2. The cladograms clearly showed three groups within the genus Bothrops. One of the groups was formed by the representatives of $B$. alternatus, B. neuwiedi, B. cotiara, and B. jararacussu. These results were in concordance with those of Werman (1992) who showed that $B$. neuwiedi and B. alternatus was within the same group based on the absence of lacunolabial scale. Also, Salomão et al.(1997) using mitochondrial DNA sequencing, confirmed the inclusion of $B$. alternatus and B. cotiara within the same group (they did not include $B$. neuwied $i$ in their study). However, other authors, such as Fernandes and Pesantes (1989) considered $B$. alternatus and B. cotiara within one group and $B$. neuwiedi in an other. The studies of Pesantes (1989), Werman (1992), Salomão (1997), and the present study, disagreed about the position of $B$. jararacussu, and its phylogenetic relationships remain unclear.

Another group was formed by $B$. insularis, $B$. jararaca, and $B$. erythromelas. These results agreed with Fernandes and Pesantes (1989) who considered B. jararacussu, B. insularis, and $B$. jararaca to be within the same group, and Salomão (1997) who considered B. insularis to be a sister taxon of $B$. jararaca. However, our results showed that $B$. erythromelas, been associated to $B$. neuwiedi (Fernandes and Pesantes, 1989; Werman, 1992) strongly clustered within the jararaca group. Considering the high values of confidence $(95 \%)$ obtained with bootstrap analysis, the present data suggested that $B$. erythromelas should be included in the jararaca group. However, additional data would be necessary to confirm this hypothesis.

The third group was formed by $B$. moojeni, $B$. leucurus, and $B$. atrox, three species that made part of the atrox group. These results agreed with those obtained by electrophoretic analysis of plasma proteins and hemipenis morphology (Fernandes and Pesantes, 1989), izozyme electrophoretic profiles and morphological data (Werman, 1992), and mitochondrial DNA sequencing (Salomão et al., 1997). While a discussion of the technique adopted (RAPD) is beyond the scope of our article (see reviews by Hadrys et al., 1992; Hillis et al., 1996), several general concerns should be noted. Although the patterns obtained by RAPD are extremely sensitive to reaction conditions and care must be taken to ensure reproducibility, when standardize experimental conditions are established, the technique offers reliable results. RAPD is considered as a efficient tool for species identification (Hillis et al., 1996), and despite controversies, it has been applied successfully in the evaluation of interspecific relationships of many different organisms, including reptiles (Ryabinina et al., 1997). Moreover, RAPD offers the opportunity to access information about a large portion of the genome.

Considering that RAPD analysis was consistent with the morphological and biochemical data previously reported, RAPD markers could be seen as a reliable method for both species identification and the evaluation of genetic relationships among snakes of the genus Bothrops. Moreover, RAPD offers the possibility of obtaining valuable information of reptiles with nonlethal sampling (shed skin or blood). 


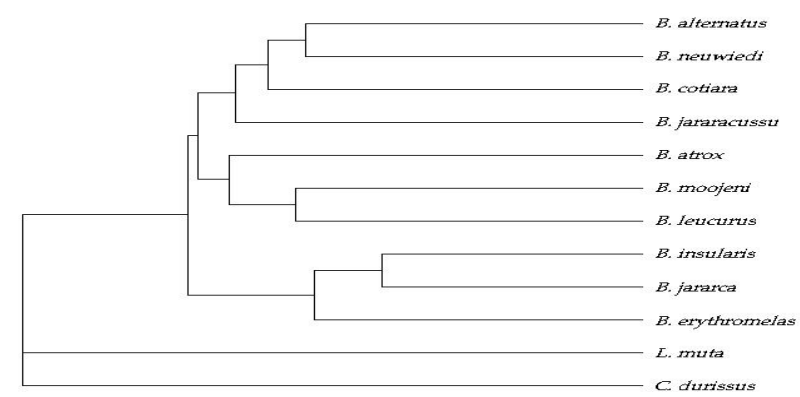

A

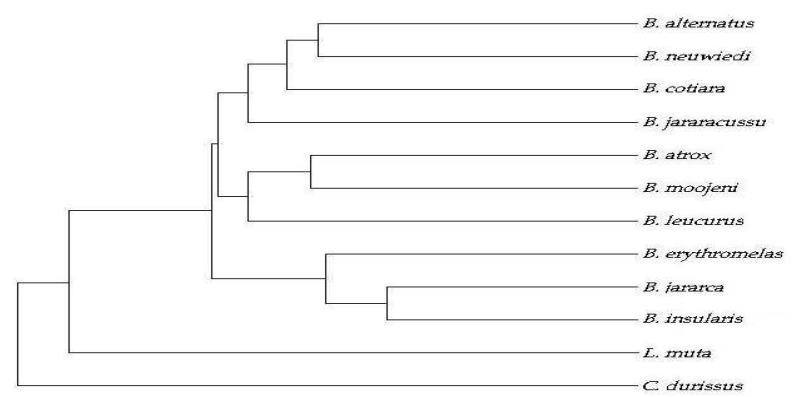

B

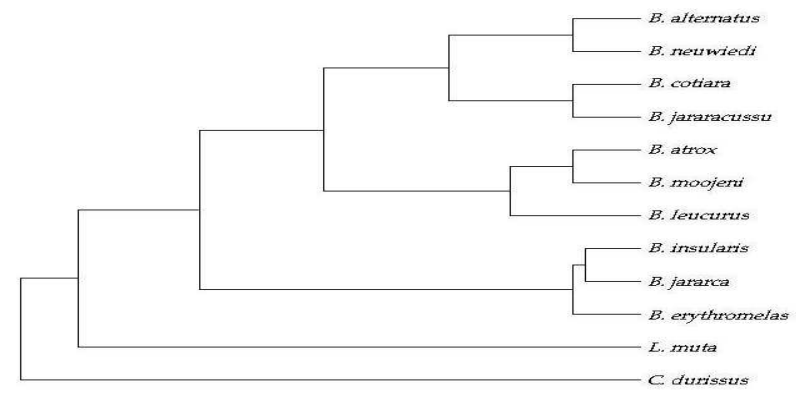

C.

Figure 2 - Phylogenetic trees for the species of Bothrops obtained through the use of three different algorithms. (A) Neighbor-joining, (B) Fitch-Margoliash, and (C) Polymorphism Parsimony (consensus tree obtained from two equally parsimonious trees).

\section{ACKNOWDLEDGMENTS}

This research was supported by the University of Caxias do Sul, FAPERGS and CNPq. We thank M. F. Furtado and G. Porto from the Instituto Butantã, M. L. Araujo from Fundação ZooBotânica of Rio Grande do Sul; G. Pontes form the Pontificia Universidade Católica of Rio
Grande do Sul; and P. J. Demeda of the Museu de Ciências Biológicas of the University of Caxias do Sul, for providing specimens of Bothrops. We also thank T. de Lema for help and advice. 


\section{RESUMO}

As relações genéticas entre 11 espécies de Bothrops (sensus stricto) de ocorrência no Brasil foram determinadas através da comparação dos perfis de fragmentos amplificados aleatoriamente (RAPD). Um total de 239 bandas foram obtidas utilizando 20 sequencias iniciadoras (primers). A maior parte das bandas (88,7\%) foram polimórficas. A análise filogenética dos dados permitiu a identificação de três grupos dentro do gênero Bothrops: Grupo 1- $B$. alternatus, $B$. neuwiedi, B. cotiara, e B. jararacusu; Grupo II- B. insularis, $B$. jararaca, e B. erythromelas; e Grupo III- B. moojeni, B. leucurus, e B. atrox. Estes grupos coincidem com aqueles obtidos por outros métodos indicando que os marcadores de RAPD podem ser considerados ferramentas úteis para a avaliação de relações a nível interespecífico.

\section{REFERENCES}

Amaral, A. (1921), Contribuição para o conhecimento dos ofídios do Brasil -A. Parte II. Biologia da nova espécie, Lachesis insularis. Anex. Mems. Inst. Butantan Secc. Ofiologia, 1, 39-44.

Branch, B. (1973), The collection of blood by cardiac puncture from surgically anesthetized snakes. $J$. Herp. Assoc., 11, 5-6.

Brasil. Ministério da Saúde (1991), Coordenação do controle de zoonoses e animais peçonhentos. Ofidismo, análise epidemiológica. Brasília. pp. 49.

Bricker, J., L.M. Bushar, H.K. Reinert and L. Gelbert. 1996. Purification of high quality DNA from shed skin. Herpet. Rev., 27, 133- 134.

Campbell, J. A. and Lamar, W. W. (1989), The venomous reptiles of Latin America. Ithaca, New York : Cornell University Press.

Cardoso, J. L. C. (1992), Introdução ao estudo dos acidentes por animais peçonhentos. In: Shvartsman, S. (Ed.). Plantas venenosas e animais peçonhentos. São Paulo : Sarvier. pp. 139-142.

Crawford, D. J. (1990), Plant Molecular Systematics: Macromolecular Approaches. New York : John Wiley and Sons. pp. 388.

Echeverrigaray, S.; Grazziotion, G.; Grazziotin, F. and Agostini, G. (2001), Random amplified polymorphisms between two South American subspecies of rattlesnakes (Crotalus durissus collilineatus and Crotalus durissus terrificus). Braz. Arch. Biol. Techn., 44, 313-317.

Felsenstein, J. (1993), Phylogenetic Inference Package (PHYLIP), version 3.5c. Department of Genetics, University of Washington, Seattle.
Fernandes, W. and Pesantes, O. (1989), Relacionamento entre as espécies do grupo Bothrops (Serpentes: Viperidae) pela eletroforese do plasma. In: Congr. Bras. Zool., 13., Cuiabá. Procedings... pp. 179.

Hadrys, H.; Balck, M. and Schierwater, B. (1992), Applications of random amplified polymorphic DNA (RAPD) in molecular ecology. Molec. Ecol., 1, 55-63.

Hillel, J.; Schaap, T.; Haberfield, A.; Jeffrey, A. J.; Plotzky, Y.; Cahaner, A. and Lavi, U. (1989), DNA fingerprinting of poultry. Animal Genetics, 20, 25-35.

Hillis, D. M.; Mable, B. K. and Moritz, C. (1996), Applications of molecular systematics. In: Hillis, D. M.; Moritz, C. and Mable, B. K. (Eds.). Molecular Systematics. Sunderland, MA : Sinauer Ass. Inc. pp. 515-544.

Hoge, A. R. and Romano-Hoge, S. A. R. W. L. (1978/79), Poisonous snakes of the world. Part I. Checklist of the pit vipers, Viperoidea, Viperidae, Crotalinae. Mems. Inst. Butantan, 42/43, 179-310.

Masters, B. S. (1995), The use of RAPD markers for species identification in demognathine salamenders. Herpetol. Rev., 26, 92-95.

Moritz, C. and Hillis, D. M. (1996), Molecular systematics: context and controversies. In: Hillis, D. M.; Moritz, C. and Mable, B. K. (Eds.). Molecular Systematics. Sunderland, MA : Sinauer Ass. Inc. pp. 1-16.

Patterson, C.; Williams, D. M. and Humphries, C. J. (1993), Congruence between molecular and morphological phylogenies. Ann. Rev. Ecol. Syst., 24, 153-188.

Pesantes, O. C. (1989), Relações entre algumas espécies do gênero Bothrops, pela eletroforese do plasma e morfologia do hemipenis (Serpentes: Viperidae). MSc dissertation: Univeridade Estadual Paulista Julio de Mesquita Filho, Rio Claro, São Paulo.

RoHLF, F. J. (1992), NTSYS-PC: Numerical taxonomy and multivariate analysis system. New York : Exeter Software.

Ryabinina, N. L.; Grechko, V. V. and Darevsky, I. S. (1997), Randomly amplified polymorphic DNA (RAPD) in studying of lacerta intra and interspecies relationships. In: World Congress of Herpetology, 3., Prague, Czech Republic. Annals...

Salomão, M. G.; Wüster, W.; Thorpe, R. S.; Touzet, J. M. and BBBSP (1997), DNA evolution of South American pitvipers of the genus Bothrops (Reptilia: Serpentes: Viperidae). Ann. Symp. Zool. Soc. London, 70, 89-98.

Schätti, B. and Kramer, E. (1993), Ecuatorianische Grubenotten der Gattungen Bothriechis, Bothrops und Porthidium (Serpentes: Viperidae). Rev. Suisse Zool., 97, 877-885.

Weising, K.; Nybon, H.; Wolff, K. and Meyer, W. (1995), DNA fingerprinting in Plants and Fungi. Boca Raton, Florida : CRC Press. pp. 320. 
Werman, S. D. (1992), Phylogenetic relationships of Central and South American pitvipers of the genus Bothrops (sensu lato): cladistic analyses of biochemical and anatomical characters. In: Campbell, J. A. and Brodie, E. D. (Eds.). Biology of the Pitvipers. Texas : Selva, Tyler. pp. 21-40.

Williams, J. G. K.; Kudelik, A. R.; Livak; K. J. and Rafalski, J. A. (1990), DNA polymorphisms amplified by arbitrary primers are useful as genetic markers. Nucleic Acids Res., 18, 7213-7218.

Received: April 07, 2004; Revised: June 17, 2004; Accepted: November 22, 2004. 